\title{
Women in Peace Education
}

\author{
Dr. Bakky Ngozi Adirika \\ Department Of Educational Foundations, Nnamdi Azikiwe University, Awka.
}

\begin{abstract}
This paper aims at sensitizing women on the need for a continued action for effective involvement in decisions about peace in their immediate environments and in the world at large. The paper hopes to achieve this by explaining the concept of peace education, its components, its processes, the role of women in conflict and peace situations among others. It is hoped that these would not only inform women better on peace education but also encourage them to extensively engage in it for the development of a better society and a better world.
\end{abstract}

Key words: Women, peace, Education, Empowerment, conflict

\subsection{What Is Peace Education?}

\section{Introduction}

Peace education has been referred to as Education for Conflict resolution, International Understanding and Human rights, Global Education Critical pedagogy.(Frances, 2005) It is also regarded as Education for Interaction and Empowerment, social justice education, life skills education and more (Potter, 2005). Using the term peace education helps to co-ordinate such global initiatives as well as unites educators in the common practice of educating for a culture of peace.

Peace education is directed to the full development of the human personality and to the strengthening of respect for human rights and fundamental freedoms. It promotes understanding, tolerance and friendship among all national, racial or religious groups. Peace education started after the establishment of the United Nations in 1954. The UN was set up after the world wars to save succeeding generations from the scourge or war, to reaffirm faith in the dignity and worth of the human person, in the equal rights of men and women, to establish conditions under which justice and respect for the obligations arising from treaties and other resources of international law can be maintained as well as to promote social progress and better standards of life in Larger Freedom (Preamble to UN Charter).

One can therefore say that peace education is an integral part of the work of the United Nations, and more importantly that kind of education which strives to promote social cohesion and reduction of violence in the world.

Notice that no attempt has been made to separate the concepts of education and peace thus far. This is intentional; the simple reason for this is the realization that education has a direct bearing on peace. Why this kind of submission? Anuradha (2006) believes that education can be seen as enlightenment, creation of awareness, appreciation of self and societal values, doctrines, philosophies, norms, beliefs as well as the development of self such that one can be most beneficial and productive to both self and society. The above definition portends education as light, something that helps one to see issues and events around one and within one clearly, not just for one's own selfish ends but for the good of all. Odock (2006) asserts that a truly educated society is also a caring society. Odock points out that disaffection needs both understanding and tolerance, and that disaffection must be eradicated if the best use is to be made of the world's most natural resources - people. The implication here is that if education is not used to resolve the issues of ill-discipline, alimentation, disaffection and disadvantages then the society is increasingly likely to feel the backlash from the ever increasing pool of dissatisfied adult-which situation, if not duly checked, could contribute to a more violent society than is currently evident.

Peace is understood not just as the absence of traditional forms of direct violence, but also as a positive presence of love, security, wealth, to mention these few. . Peace education has developed as a means of achieving all the aforementioned goals and needs.

\subsection{Components of Peace Education}

UNICEF and UNESCO are particularly active advocates of Education for Peace. UNICEF (2001) describes peace education as schooling and other educational initiatives that:

- $\quad$ Function as 'zones of peace' where children are safe from violent conflict.

- $\quad$ Uphold children's basic rights as outlined in the Child's Rights Charter (CRC)

- $\quad$ Develop a climate that models peaceful and respectful behaviour among all members of the learning community. 
- $\quad$ Demonstrate the principles of equality and non discrimination in administrative policies and practices.

- $\quad$ Draw on the knowledge of peace-building that exists in the community including means of dealing with conflict that are effective, non violent, and rooted in the local culture

- $\quad$ Handle conflicts in ways that respect the rights and dignity of all involved.

- Integrate an understanding of peace, human rights, social justice, and global issues throughout the curriculum whenever possible.

- $\quad$ Provide a forum for the explicit discussion of values of peace and social justice.

- $\quad$ Use teaching and learning methods that stress participation, cooperation, problem solving and respect for individual and group differences.

- $\quad$ Enable children to put peace-making into practice in the educational setting as well as in the wider community.

- Generate opportunities for continuous reflection and professional development of all educators in relation to issue of peace, justice and rights (Peace Education in UNICEF-working paper Series, July, 1999)

Part of the work of UNESCO is centered on the promotion of education for peace, human rights and democracy. The notion of a culture of peace' was first elaborated for UNESCO at the International Congress on Peace in the Minds of Men, held at Yamoussoukro, Cote d' Ivoire, in 1989. The Yamoussoukro Declaration called on UNESCO to construct a new vision of peace by developing a peace culture based on the universal values of respect for life, liberty, justice, solidarity, tolerance, human rights and equality between women and men, and to promote education and research for this vision (Amalita, 2008). From UNICEF and UNESCO's efforts at outlining what peace education involves, it is easy to appreciate that peace education brings together multiple traditions of pedagogy, theories of education and international initiatives for the advancement of human development through learning. It is fundamentally dynamic, interdisciplinary and multicultural. It grows out of the work of educators such as John Dewey, Maria Montessori, Paulo Freire, John Galtung and many others.

Building on principles and practices that have evolved over time and responding to different historical circumstances, peace education aims to cultivate the knowledge, skill and attitudes needed to achieve and sustain a global culture of peace. Understanding and transforming violence are central. Peace education rises against such direct violence as personal assault, rape, brutality, terrorism, murder, ethnic cleansing, institutional war, state sponsored terror, industrial destruction of plant and animal life, as well as indirect violence such as sexism, racism, discrimination, poverty, hunger, lack of education and health services among others. Peace education on the other hand, while favouring the absence of personal and institutional violence, is more disposed to working to ensure the presence of well being, social justice, gender equity and human rights. Educating for all aspects of peace constitutes Peace education.

\subsection{Process of Peace Education}

Here it is intended to present avenues and demonstrations of how peace education is enhanced and fortified in this part. Many teachers are already practising peace education without calling it by name. Peace education had earlier been described in this paper as education for liberation and empowerment, life skill education, disarmament and development education and more. In the classroom, peace education aims at developing skills, attitudes and knowledge with co-operative and participatory learning methods, and an environment of tolerance, care, and respect. Through dialogue and exploration, teachers and students engage in a journey of shared learning. Students are nurtured and empowered to take responsibility for their own growth and achievements while teachers care for the well being of all students. The practice of peace education is an opportunity to promote the total welfare of students, advocate for the just and equitable treatment of youth, promote individual growth and social responsibility for both educators and learners. Through pedagogy and social action, peace educators demonstrate that there are alternatives to violence.

Outside the classroom, peace education can also take place. It can use all the processes employed inside the classroom to also achieve the same effect, outside of the classroom. The processes adopted by educators, researchers, activists and members of the global civil society can all be applied to achieve peace education. Acting in partnership with United Nations and its specialized agencies, Non-governmental Organizations (NGOs), educational institutions and citizens' networks have advanced education for peace by linking ideals with extensive research and practice. A culture of peace will only be achieved when citizens of the world understand global problems, have the skills to resolve conflict and struggle for justice non-violently, live by international standards of human rights and equity, appreciate cultural diversity, and respect the earth and each other. Such learning can only be achieved with systematic, sustained, and participatory education for Peace (Hague Appeal for Peace, Global Campaign for Peace Education). 


\subsection{Why should Women engage in Peace Education?}

The woman, according to Hornby Dictionary of Current English, is an adult human female, an instinctive resource, a member of the fair sex. Women is the plural form of woman. Women therefore, must involve in peace education because they are first and foremost, humans, flesh and blood, affected by every issue that affects the human race. They should involve in peace education because they are involved! They exist!!!

United Nation's report for year 2000 on the world's population broadcast on BBC world service in January, 2001, clearly indicated that women constitute $51 \%$ of the world's total population. This simply means that women are in the majority. Women dealing directly with peace education implies that majority of the world's population are working towards the peaceful co-existence of all humans in the world. Peaceful coexistence cannot be negated by any progressive minded set of humans, whether they are in the minority or in the majority. When they are in the majority, it is even better!

By their very nature, women are regarded not just as members of the fair sex but also as members of the weaker sex. Whether this assumption is right or wrong is not the focus here. The point which is being made is that women need peace as an assurance of their own safety and survival. People have argued that all is fair in war but the women's stance is that war does not create fairness. Education being a positive chart, could direct towards fairness, the type of fairness that makes war unnecessary. Women need to involve in peace education in order to assert this stance on fairness.

From lessons learnt from existing conflicts and wars, women and children are most vulnerable during conflicts. They are the worst hit. Their children suffer hunger and disease, their husbands and fathers are killed and maimed, they are raped and overburdened in less peaceful settings and situations. It is therefore, important that women concern themselves with situations that give rise to peace as well as to situations that sustain peace in order to save themselves and the world some bitter agonies (Boulden, 2004)

Violent death among reproductive aged women occur more in conflict situations. Child bearing is stressful and needs comfortable and positive psyche as people work at it. In conflicts and during wars, medical supplies are not at their best because of restrictions associated with wars and conflicts. The result is that many women die within such periods at child birth. Rape victims in most cases are women and violent deaths can result from varicose-vaginal diseases and other complications. These violent deaths have sobered and humiliated women so much so to the realization of the effects of violence and absence of peace in individual or group development, growth and survival. If women of reproductive age are allowed to go extinct without a fight, then the world's population may be unfairly thinned down. Involvement in peace education will give women opportunity to educate and socialize their children and the world against the incidents that give rise to violent deaths.

Harmful traditional practices on women such as early or child marriage, domestic violence, sexual violence, widowhood practices to mention these few, exert so much pain that women are in dare need of a peaceful co-existence to lessen their level of pressure and depression. They must therefore, involve in peace education for their own healthful living. Unless women get involved in peace education, they may continue to suffer physical violence in their cultural and traditional settings especially in Nigeria and Africa. Peace reduces physical violence, which in turn, secures the physical and psychological sense of security of children, and by implication enhances the children's rapid growth and development into qualitative personalities. Violence is a destabilizing agent and the sooner it is curbed, the easier it would be to achieve stability and development, whether for the individual or for the group to which he belongs.

Peaceful co-existence is a fundamental human right. Women have to pressurize for their rights and assert themselves. Human rights are also women's rights and women should claim and work towards the realization of such rights. Respect and peaceful co-existence is part of these rights. Education is a tool for their realization.

Man finds joy and comfort in companionship, yet living together is not easy. To be a full and positive man, one must live and grow up among his fellow men in a given group, family, nation or generation. To survive, he must share and accept some of the sentiments, norms, and values of the group in which he finds himself. Survival also demands that man must be able to satisfy his needs or continuously tackle tasks as well as face the problems involved in securing the necessities of life in society. The task of making the individual fit into and play his part in society is the function of education and socialization. Women, being part of the generic man, cannot afford to abandon this task without a second thought. It is through their involvement in education and education for peace that they can work towards proper socialization, education and stability of the individual and the nation. Women should also work at peace education with authority and assertion whether they are welcome to it or not, whether they are invited to it or not. 


\subsection{Comparative Advantage}

How and where does the Woman derive her power for participation in Peace Education?

Women's power and comparative advantage is centered in the womb, the cradle and the kitchen. Call it the three pillars of female power. It is anchored in the natural position and role of women as brides, wives and mothers. These natural and divinely given positions have been exploited positively for the advancement of the world severally. They must continue to be used positively for all times.

While the man asserts authority in the family, by causing the women and the children to obey his whims and caprices, he sees himself as the pillar and bread winner of his household. Yet as wives and brides, women skillfully manage husbands with some potential successfully to produce enough wealth, status and power to satisfy the family and society. An acceptance of this view is summarized in the saying that behind or beside every successful man, there is a woman. As a mother, the woman enjoys a mysterious closeness culminating in deep respect and gratitude for world's nurturers and first teachers. This mother power can be used as the conduit for the transfer of peace behaviour through mother's education and expectations. Whether as bride, wife or mother, the woman derives therefore, a naturally endowed power and advantage that keeps her in a position to manipulate the world positively to achieve peace.

Women also derive authority, by implication, from the government to involve in peace education. This power arises from her civic obligations. Women are found in almost all offices, organizations and in fact all places. They join in planning, advising, organizing and solving problems in their respective places. As direct staff and participants who work for the common good of all, women have every opportunity to panel beat peace motives into their suggestions and submissions. Neglecting such strong awareness of fostering peace would be very pitiable indeed.

In this era of globalization, the government of the day considers global implications of actions and/or inactions seriously. By encouraging women to publicly involve in peace education, the government would have constituted another formal elevation of women from their culturally ordained kitchen roles and thrust them further into public institutional settings outside the home. That way, the government signals to the citizens and to the world at large, their commitment to the integrity of their political structures and protocols. It would thus be a clear indication that women are consistently being moved into key administrative and decision making positions alongside men in the formal state apparatus and in the multinational private sector. Peace is both a political, individual and Government issue. Government, by involving women in peace education, would be building consciously, and conspicuously, stronger humanitarian political, institutions.

\subsection{Role Of Women In Peace Education}

If education is enlightenment, (Anuradha, 2006), then women have the important role of dispelling popular nonsense. The need to correct popular misinformation, misconceptions and superstitions which becloud much of society and social thinking cannot be overemphasized. Changes must be effected in erroneous beliefs against women and children particularly. Interactionist theory focuses on interaction or/and actions between individuals. Interactionist perspective seeks to explain the ways individuals act towards, respond to and influence one another. Issues and things (realities) do not exist independently of human actions; therefore society's ultimate realities are created and sustained by the social interaction of its members. Superstitions are notions born out of man and sustained by man. When biased, they act to the detriment of the prejudiced. Awareness brings, not only realization but also inspires reconstruction. Women in peace education, by dispelling popular nonsense militating against women and children in society, would be in the real sense, working towards the positive reconstruction of society for enhanced development.

Researches provide data and insights that best debunk popular nonsense. Women should research into different aspects of human social life either as individuals or in groups. These researches could help to discover and reorganize knowledge obtained from society about issues and events that can disrupt or destabilize peaceful societal existence. Whether women are employed in universities, government agencies and departments, research foundations, hospitals, non governmental organizations, or are in markets as traders, or even as community workers, they should strive to attract grants from donor agencies and NGOs for research initiatives and research enhancement. Results of such researches embarked upon or commissioned by them, should be pushed back into society through conferences, documentations, seminars and so on; for solving women's need, those of the donor agencies or their associates. Peace researches are needed more than ever in this age of globalization and technology. Women could play the role of Peace researchers and research sponsors effectively and multifacetedly.

Women could make peace predictions. This is another important role emanating from involvement in research. Evidence unearthed and discovered in research should be intelligently applied by women to make predictions. Even if such predictions fail to forecast anything more than the probable pattern of events to be expected, women should venture into predicting peace. Such predictions and forecasts can be used to form sufficient bases for formulating social policies related to peace. To do this, women should rely on certain 
informed assumptions about the present and future state of the society. Such assumptions are developed out of a good understanding of the working of society or its parts-in itself a product of study and research. Women can conveniently, following the pattern already exhibited by some women in office, for example the likes of Ngozi Okonjo-Iwuala, Grace AleIe-Williams, Oby Ezekwesili, Jadesola Akande, Farida Waziri, Dora Akunyili and many others, to predict the continuation of corruption in state affairs until such people are allowed to take up the mantle of leadership greater in scope than what they had or have at the moment. Such predictions will make it possible for a unified, focused plan for societal development which also translates to peace development. Women can also provide the intellectual framework for such peace planning.

Women can serve as peace consultants. Every policy decision is intended to produce desired effect or achieve set goals. Policies not based on sound assumptions and predictions often fail. Women have their ears to the ground and mingle much with the masses. They are in a better position or stead to assess potentials and situations in terms of anticipated results. Women should be in a position to advice, even if they are uninvited, through the media, and through representations on the propriety or otherwise of many policy issues that may relate to peace and stability in society.

Women can also be public advocates of social actions. They should hold value preferences and make these preferences known to all and sundry. The era of value neutrality is over. If women fail to be assertive themselves, they will not be asserted. Value commitment should replace value neutrality. Women should openly and publicly support issues, policies, and actions that suit and agree with peace in society. They should also rise against inactions that undermine the development and sustenance of society, group and individual peace. What they advocate for should take root from the convictions stemming from research findings. They should participate, by affirmative actions and demonstrations, and in fact, through any other ways possible, in issues such as how poverty can be reduced, crime curbed, problems of ethnic and religious conflicts resolved, and political partnership developed. They should speak out publicly against drug addiction, rape and other vices, saying what they want the society to do about such problems and issues. Women should outline values that need to be given up either by individuals, family members, the ruling class, groups and indeed the society - in order that peace would thrive in the world. They should use whatever techniques they consider effective to assert their peace initiatives -whether they are sanctions, pressures, and criticisms - all aimed at violent people in their respective communities and settings.

It is indeed gratifying to note that recently, some women and groups of women have united in some places to assert and participate in peace processes all over the world. It is perhaps important to cite some of these in order to buttress on how women can get involved in Peace education and peace processes.

\subsection{Some Efforts Of Women In The Development Of Peace Processes.}

It had earlier been shown and implied that peace education is development related. Social conflicts on the other hand are caused and sustained by the different desires and tendencies of individuals in society as well as the interplay of the unresolved internal conflicts of the individuals in society. Efforts have variously been made by women to discourage the sustenance of conflicts in the world. It has also been shown that women's participation in peace processes have helped to produce long term successes because women have been known to adopt more inclusive approaches towards security. They address key social and economic issues that might otherwise be ignored yet such exert a lot on peace initiatives (Boulden, 2004)

The 2005 Dafur peace agreement is quite encouraging in terms of women's involvement and their concomitant achievements. Gender Expert support team of 20 women, backed by the UN, Canada, Norway and Sweden was invited to participate in the $7^{\text {th }}$ and decisive round of the Dafur Peace agreement negotiations. These experts gathered women from the various ethnic groups in Dafur and worked with them in unity to itemize the women's priorities packaged in the document "Women' priorities in the peace process and reconstruction of Dafur'. The provisions in the document related to women and children sought for specific protection for women and children in conflict situations, priority treatment for women and children in assessments related to compensations/ reparations for damages and destructions caused by war. They also appealed to the government to pay particular attention to the education of women and children as a means of ensuring security as well as for the provision of secondary schools in refugee camps and for internally displaced persons. A call was also made to the international community to focus on the education needs of refugee girls, a creation of an institution to provide legal support, psychological counselling and other relevant services to women and children (Quintus-Deles, 2006).

In December 2002, in Sri Lanka, women were active in drawing the agenda for the peace process. This led to the focus on gender dimension of post conflict reconstruction which had as its priorities, the equal representation of women in politics, educational structures, gender bias and violence against women and girls.

In Somalia in 2000, 92 women delegates to the Somali National Peace Conference presented themselves as the $6^{\text {th }}$ clan for peace. Despite the resistance they suffered from the men, they still helped to draft a national charter that guaranteed women 25 seats in the 245 member transitional National Assembly (Rhen \&, Sirleaf, 2002). 
Again in Burundi in 2000, Burundi women overcame the resistance of the Burundian parties and were included as informal observers in Peace talks held in Anisha, United Republic of Tanzania (Auderlini, 2000).

Representatives of over 200 women organization met in 1996 to create the Northern Ireland Women's coalition, the first female dominated political party. The movement included members from both protestant and catholic communities and they worked as a cross community party to promote civil, human and workers' rights (Aolain, 2003). The coalition was eventually credited by George Mitchell, the US senator who mediated the Northern Ireland peace talks with helping to achieve an agreement in those negotiations (Sultan, 2005).

In the Guatemala Peace process of 1996, the participation of women led to a national health programme for women and girls and a programme to reunite families and locate missing or separated children and orphans. In Philippines, women have held influential positions in formal peace processes and have pushed for co-operations across party and religious lines in the interest of peace. (Kelly, 2004) In .Sierra Leone, two women were involved in the Lome peace process. Though they were not the key negotiators, yet their presence ensured a key article in the final agreement that called for special attention to be paid to victimized women and girls in formulating and implementing rehabilitation, reconstruction and development programmes (Mazurana \& Khristopher, 2004). In the Liberian Peace talk of 1994, women initiative was not granted official participant status but the Librarian women's initiative and her leadership proved to be highly influential to consultants during the process (Anderlini, 2000).

Wars and rumours of war must constitute an opportunity for change. Women should wake up inspite of all odds; they must struggle on inspite of concerted efforts to stop them. The Burundi women struggled to get money to find 2 taxis that kept them on the road for two days while the men travelled in officially sponsored planes that took less than I hour to get to Anisha; yet the women eventually arrived! That should inspire the present and future generations in the effort at peace building and peace education. What has already been done by women in local government and peace processes are not only transforming the politics of the present but is also altering its future. There is growing confidence in women's leadership abilities and women should further exploit this situation to launch themselves higher on the ladder of governance. More women should venture into politics with a stubborn determination. Women in politics advocate more often and more strongly for rights of women, children and families.

\subsection{Women as Mediators and Peace Keepers}

A District officer from the Huri Province in the Democratic Republic of the Congo explained in a report to the UN department of peace keeping operations (DPKO) that local women have difficulty in talking freely to uniformed men such as male military observers, especially about sensitive issues such as sexual violence and abuse. He commented that they fear further violence including from male peace keepers. That report underscored the need for increased presence of women among peace negotiators and peace keeping forces. Unfortunately, women are not encouraged by their husbands and sons to join peace negotiating and peace keeping forces. Where the women are unmarried but have parents living, their fathers discourage their participation and enlistment. However, the very few women who eventually get there are not just willing but are also able to work as military observers even in war zones (Potter, 2005).

With that report, one can assume that the UN is aware of the situation, yet only about $4 \%$ military and $1 \%$ police force that are women are deployed by DPKO. To deal with the small women representation in the forces, the number of women holding civilian positions has increased. This is perhaps connected with the key finding of an investigation initiated by the UN Secretary General on the presence of women in a peace keeping mission, especially at senior levels. Part of the findings of that investigation clearly indicate that the more the number of women, the more sexual exploitation and abuse are discouraged and reduced, particularly of the local population.

Apart from peace keepers, mediators that represented international community can act as 'tipping points' to help women secure representation in peace processes and post conflict reconstruction. Unfortunately, participation of women in peace process as 'track one' - mediators involved in official negotiations through formal channels, as well as 'track two' - mediators through unofficial channels, remain largely miniscule and sometimes out rightly excluded. Even at the UN, only $6.5 \%$ women hold senior peace related positions. In the European Union (EU), no woman at all is among the current and former high level mediators. In Africa, inspite of the presence of strong female role models, no woman is in the peace and Security Council of the African Union (AU). It is only Uganda that stands out for the presence of a love female mediator (Potter, 2005).

Unless women increasingly and determinedly involve in peace education and negotiations, it would really be difficult to weld that environment in which they can make a difference. There may still be a long way to go, but the plan must be made clearer, the path better defined and actions painstakingly focused. 


\subsection{Challenges and Opportunities}

The UN, UNICEF and UNESCO have been described as active advocates of education for Peace (Potter, 2005). These organizations and many more others directly and indirectly involved in peace education and peace processes are really appreciated for their roles and efforts. Some of these bodies and groups have worked assiduously to support women in their strivings at peace impartation, negotiations and conflict reconstructions, advocacies and actions, a culture of peace has not yet been established. People must therefore not rest on their oars particularly women!

Framework and rationale for peace education still embrace so much that the enormity it represents could be scary. It has been referred to as liberation and empowerment, social justice education, environmental education, life skill education, disarmament and development education, global education, education for conflict resolutions, international understanding and human rights, critical pedagogy and more! Much as these various labels illuminate the depth and diversity of the field, concerted effort should be made to streamline what peace education represents and should focus on it in global terms.

The years 2001-2010 were declared the international Decade for a culture of peace and Non violence for the children of the world (UN Doc A/RES/52/25). The UN Cyberschoolbus Peace Education site enjoined the global movement to build and sustain a culture of peace through education. Yet many nations of the world have no departments for the development of curriculum for peace education in their ministries of education. It is already well past 2010 and one wonders how long there is before changes would be significantly effected.

Contents of peace education is not the only problem in peace education implementation, specific methods for its actualization seem not to have been clearly identified. In fact, advocates of peace education continue to say that peace education brings together multiple traditions of pedagogy, theories of education and international initiatives for the advancement of human development through learning. International efforts must have drawn from educational initiates all over the world to form the basis of peace education objective. Teaching units and methodologies to be used for their achievement may not have gotten into the hands of all who desire to involve in it and time is running out. Knowledge, skills and attitudes required for peace development are various and intricate. There is need for the development of conducive environments for practical experimentation and trial of such skills, knowledge and attitudes. A variety of different educational settings from rural to urban, school based to community, and within formal curricula and non-formal popular education projects need be put in place to enable educators work and shape the specific content and methods they consider relevant for such knowledge, skills and attitudes required for effective peace education.

At the moment, educating for peace is as varied as the teachers who practice it whether they are men or women. Moreover, various aspects of peace education may serve to enhance learning across subjects as shown in past conflict resolution initiatives in the United States-yet little effective co-ordination of peace education teachers has been done.

Practical experience in the teaching profession shows that peace education exists in the classroom. Teachers are known to appoint prefects who may be males or females to help maintain a conducive atmosphere for learning. These prefects mediate between their fellow students when they have problems in the absence of their teachers. This is an aspect of peace education.

Teachers also use instructional methods and strategies that enhance peaceful coexistence and cooperation among their students. Some popular instructional methods as the project methods, discussion method, play way method, assignment method, group methods, peer method, used often by teachers in various classrooms, provide training in team work and positive interpersonal relationships among students. Team teaching as an instructional strategy also builds bridges that connect teachers themselves on one hand, and then teachers and students on the other hand. Play way method and discussions offer ample opportunity for pupils and students to learn to listen to others, respect others' opinion, take turns and learn to wait patiently for their own turns as well. Peer teaching is another strong motivational strategy that gives learners opportunities to relate and intermingle in the classroom. Teachers apply these methods and strategies variously and for various reasons. The important thing to note, however, is that they happen in teaching and learning classrooms frequently and almost everywhere.

Even outsides the classroom, peace education take place. How does one explain the various sporting activities that take place in schools? What of the excursions and the visitations that are undertaken under the auspices of the school that may not be within the confines of the schools and classrooms? How does one also derive the several groupings, clubs and associations that are formed in the school but which may also function outside the school such as Boy Scouts, Girls Guides, Man 'O' War, Red Cross Society, Farmers club, Young Scientists to mention only these few?

\subsection{The Way Forward}

Peace education does not just teach students what to think, but rather how to think critically. Its holistic and participatory approach may therefore, conflict with more traditional curriculum designs or strict standard- 
based schooling. Initiators must not be discouraged because peace education aims not to reproduce but to transform. It consists of people consciously striving to educate their successors not for the existing state of affairs but also to make possible, a future and better humanity. Newer and more dynamic approaches to educational efforts must therefore be developed and tried out no matter how nonconforming such approaches may be to known forms and patterns.

Another way to meet the challenges of peace education is to build bridges of support among key participants. Women should therefore get together, locally, nationally and internationally specifically for the purposes of peace education. Just as learning takes place in broader social context and not exclusively in school or classroom, so peace education relies on families, communities and social networks to affect positive and lasting change. The notion think globally, act locally, must be seen as central to educating for a culture of peace. International issues are linked to individual efforts directly and indirectly, Peace educators therefore, should not work alone.

The international peace education community and advocating agencies like the UN, UNESCO and UNICEF are active and growing through networks, publications, global campaigns, national initiatives and international programmes. Women and other concerned citizens and activists of all ages around the world should access these networks, publications and so on to enhance their strategies, knowledge base and resources for effective peace education. Peace education efforts must not just be initiated but also sustained. Women, more than ever before should show their spirit of resilience and commitment in this.

\section{Books}

\section{References}

[1]. M. C. Frances, Report on conflicts, human rights and peace building; School for peace culture. (Spain: Bellaterra, 2005)

[2]. A. Potter, We the Women: Why conflict mediation is not just a job for men. (Geneva: Centre for humanitarian Dialogue, 2005)

[3]. M. Anuradha, Human society, concepts and implications (London: Routledge, 2006)

[4]. C.N. Odock, Democracy and good governance. National Open University of Nigeria (Lagos: Jexcel Commercial Security Press, 2006)

[5]. UNICEF, Early marriage, child spouses (UNICEF: Innocenti Research Centre.2001)

[6]. K. D. Amalita, Gender dimensions of globalization. A discussion Paper presented at the meeting on "Globalisation Decent Work and Gender" (Geneva: International Labour Office, 2008)

[7]. Boulden, Dealing with conflicts in Africa: The United Nations and Regional Organizations. (Basingstoke : Macmillan Publishers, 2004)

[8]. E. Rhen, E.J. Sirleaf, Women, war and Peace; the independent experts assessment on the impact of armed conflict on women and women's role in Peace Building (New York: United Nations'Fund for Women, 2002)

[9]. S.N. Anderlini, Women at the Peace Table: making a difference (New York: United Nations Development fund for Women, 2000)

[10]. M, Sultan, From Rhetoric to Reality: Afghan women on the agenda for peace: Women waging peace, policy commission; hunt alternative fund, (Cambridge: Bonn talks, 2005)

[11]. F. Kelly, A Tool for advocacy and action (London: International Alert, 2004)

[12]. C. Mazurana, D. Khristopher, Combat to Community: women and girls of Sierra Leone women waging peace (Cambridge: Massachusetts, 2004).

[13]. C. P. Conaway, Children's security in inclusive security, sustainable peace (Cambridge: Massachusetts, 2004)

[14]. UNFPA, The State of World Population 2005, The promise of equality, gender equity, reproductive health and the Millennium Development Goals (New York: UNFPA, 2005)

\section{Proceeding Papers}

[15]. T. Quintus-Deles, Corridors of peace in the corridors of power: Bridging spaces for women in governance for peace. Proc. $6^{\text {th }}$ Asian Pacific Congress of Women in Politics and Decision Making, Makati City, Philippines, 2006, 10-12

[16]. N. F, Aolain, Peace agreement as means of promoting gender Equity and ensuring the participation of Women: Northern Ireland care study EGM/PEACE/2003/EP.4, written for the advancement of Women. Expert Group meeting, Ottawa, 2003, 203-213

Online

[17]. Women, War, Peace Org. www.womenwarpeace.org/sri_lanka/sri lanka.htm. (accessed Oct. 2006) 